\title{
VERMINDERING VAN WERK-UREN IN DE FABRIEKEN.
}

\author{
(Is lang arbeiden altijd veel werk leveren?)
}

The late-hours systen relnces its vietins to state of mechanism in business, and aninaw lism in enjoynents.

Ret, Dr. HUGn, MC. NEIJ, Report of meeting al Literyool of lituly closing Association.

Ik wensch een paar woorden te zeggen betreffende bovengenoemd belangrijk onderwerp, waarbij mij een paar gesprekken voor den geest komen, welke ik eenigen tijd geleden, met twee fabriekarbeiders gehad heb. Het eerste onderhond was met een stoker, werkzaam aan een fabriek, waar gewoonlijk 12, somtijds 13 uren gewerkt wordi. Daar de man mij kende had ik het voorregt in zijn vertrouwen te deelen, en $200 \mathrm{kwam}$ het, na over zijn loon - dat niet onvoldoende was - gesproken te hebben, eindelijk op de vele werkuren. „Wat heb ik aan mijn leven," zeide hij, "geld, ja verdien $i k$, maar ik heb niets geen tijd voor mij zelven." Had de man meer vrije uren, ze zouden - ik ben er overtuigd van - niet nutteloos door hem besteed worden, want ik ken hem als een oppassend en goed ontwikkeld werkman.

Het andere gesprek was met een rondlooper op een wolspinnerij te Leiden. Aldus worden zij genoemd die de verschillende spimmolens voorzien met bet garen, dat moet gesponnen worden. Tevens moeten deze menschen zorg dragen dat de kinderen hun taak, die in het aanlasschen van draden bestaat - waarnaar zij ook aanlasschers genoemd worden met voortdurende naauwlettendheid volbrengen. Die rondlooper dan is werkzaam aan eene spinnerij, waar' van 's ochtends 6 tot s'avonds 8 uur met 2 uren tusschenpozing gewerkt wordt. Voor het grootste deel echter van het jaar zijo de werkuren, met slechts één uur tuśschenpozing, van 's ochtends 6 tot s'avonds 11 , - zegge 16 uren per dag. Daarvan zijn alleen uitgezonderd die weinige kinderen die, omdat ze van 12-1 uur de mildagschool bezoeken, een uur meer vrijaf hebben, maar wier werktijd dan toch nog altijd op 15 uren daags bepaald 
blijft. Ik vroeg den man natuurlijk hoe hij dit uithield, en hij verklaarle mij dat hij s'middlags ten 1 ure soms zoo vermoeirl te huis kwam, dat hij, voor dat hij zịn middagmaal kon gebruiken, eerst een half uurtje. moest gaan liggen. Dat was de invloed vau z.00 vele werkuren, zonder behoorlijke tusschenpozingen, op het gestel van een volwassen man. Hoe zouden nu de kinderen - laten ze zelfs alle boven den twaalfjarigen leefijd zijn - bij zulk een werktijd het uithouden? Ongevcer middernacht is het als zij, na zulk een werkdag, des avonds te bed komen, en voor half zes in den vroegen morgen, moeten zij het voor zulk een werkdag weder verlaten. Kon men's maandelijks hunne zwakke ligchamen doen onderzoeken, welke sporen van toenemende verzwakking zou men dan niet vinden? Of zouden het staande arbeiden gedurende zulk een langen tijd, de zoo langdurige opsluiting in een met weinig zuurstof gevuld vertrek, de zoo schaarsche gelegenheid voor rusten en slapen dan geene nadeelige gevolgen voor het ligchaam medebrengen?

Diegenen onzer lezers die het antwoord op deze vragen willen weten, kan ik het belangrijk werk van den zoo naauwkeurig onderzoekenden Dr. Coronel aanraden. In zijn onderhoudend geschrift , de gezondheidsleer toegepast op de fab:ieknijuerheid, een liandboek voor industrieelen, genees- en stuathuishoudknudigen" zal de lezer alles vinden wat tot de gevolgen van fabriekmatigen arbeid behoort. Geen gevolg - om zoo te zeggen - is onaangeroerd gelaten, want met de grootste naauwgezetheid heeft de kundige schrijver het stoffelijk en zedelijk leven van hen die in fabrieken arbeiden, daarin nagegaan. De toestand der jeugdige arbeiders - waar het ons het meest op nankomt - neemt in zijn boek geene geringe plaats in, en wij wenschten wel, voor dat het werd ter haud genomen, een groepje van die gedurende zoo vele uren werkende, kinderen den lezer voor te stellen. Misschien zou daardoor zijne belangstelling in hun lot nog vermeerderd worden. Wat toch kan er worden van een kind dat in zijne eerste levensjaren zoo versehrikkelijk moet werken. Zou er hier - men neme den knaap of het meisje, hetgeen helaas! dikwijls gedaan wordt, nog maar alleen als middel tot meer productie - geene verkwisting van kapitaal plaats grijpen? Immers in een gegeven staat of land heeft men toch het meest an menschen in de kracht van hun leven. En wat zullen nu deze schepsels zijn, 200 de dood hen niet vroegtijdig opeischt, als zij den middelbaren leeftijd bereikt hebben? Hoe zullen ze als vrouwen, hoe als mannen zijn? Hoe in hunne uitspanningen, hoe in hunne levenswijze?

Genoeg van dit alles, om onze oogen naar een tafereel te wenden, waaruit zal kunnen gezien worden dat de voordeelen der fabriekmatige nijrerheid kunnen worlen hehouden, en de nadeelen, door zulk een 
langen werktijd noodzakelijk daaraan verbonden, afgewend. Het is het stelsel van vermindering van werkuren, met voordeel voor meester en arbeider, door Mr. Robert Gardner, van Manchester, in praktijk gebragt. Op 22 April 1844, begon hij eene proef te nemen en wel in zijne uitgebreide spinnerij en weverij te Preston. Door een stoomvermogen van 80 paardenkracht werden zij in beweging gebragt, en 668 arbeiders vonden er hun werk in. Van 12 bragt hij den werktijd op 11 uren, en niet zeer lang na deze verandering kon reeds de verklaring worden afgelegd dat, terwijl de gang der machines slechts een weinig versneld was, dezelfde hoeveelheid goederen voor dezelfde kosten werd afgeleverd, en dat de arbeiders, zoowel zij die bij het stuk als die bij de week betaald werden dezelfde loonen ontvingen voor 11 uren als zij vroeger voor 12 ontvangen hadden.

De spinners kregen van $6 \mathrm{Jan}$. tot 20 April 1844 toen er nog 12 uren gewerkt werd, gemiddeld $38 \mathrm{sh}$. 1 d. en van 20 April tot 29 Junij 1844, verdienden zij bij 11 uren arbeids, gemiddeld 38 sh. $1 \frac{1}{2} \mathrm{~d}$.

Aan de wevers werd in eerstgenoemden termijn gemiddeld $10 \mathrm{sh}$. $l_{\frac{1}{2}}$ d. uitbetaald, terwijl het in den laatsten termijn gemiddeld 10 sh. $3 \frac{1}{2}$ d. was.

De directeur van de spinnerij verklaarde dat de snelheid slechts 2 pct. vermeerderd was, toen men 11 uren begon te werken; die van de weverij bekende dat de snelheid dezelfde was gebleven als toen er gedurende 12 uren werd gewerkt. Beide directeuren waren het er over eens dat er in dien korteren werktijd veel meer lust en vlijt bij de werklielen was waargenomen dan vroeger, dat zij meer op de minunt te werk kwamen en dat er uu door hen in den loop van den dag niet noodeloos tijd werd verspild. Zij somden verder de vele voordeelen en genoegeus op clie de arbeiders, door slechts één uur vroeger op te bouden, nu kouden smaken, en waarvan ten bewijze strekte dat de avondschool vroeger mar door 17 , toen door 96 personen bezocht werd.

Dit wat de verklaringen van de directeurs angaat; laat ons nu den meester zelven hooren die, op den 22sten Ap.il 1845, toen er door hem een jaarfeest ter eere van de goede uitkomst zijner proeve aan de werklieden gegeven werd, den volgenden brief aan hen rigtte:

„Daar ik meen dnt mijn oordeel zal gevrangd worden over den werktijd in mijne fabrieken gedurende de laatste twaalf maanden, neem ik deze gelegenheid te bat om de verklaring af te leggen, dat ik zeer tevreden ben dat er in 11 uren per dag evenveel garen en geweven goed wordt gefabriceerd als vroeger in 12 uren. Ik ben hierover zoo voldaan dat het, als het God behaagt mij dit jaar in het leven te sparen, mijn plan is om eeu verlere vermindering in de werkuren te maken en die op $10 \frac{1}{2}$ um 
daags te stellen, zonder de minste vreeze dat ik door dien maatregel schade zal lijden. Ik bevind dat mijne arbeiders met meer geestkracht cn inspanning werken, zij zijn vrolijk en oogenschijnlijk gelnkkiger. Al de argumenten die $i k$ roor langen werktijd gehoord heb, schijnen gegrond op eene aritmethische questie: brengen 11 uren zooveel voort, wat zullen dan 12, 13 of zelfs 15 uren doen? Wat de stoomkracht betreft gaat dit op; wat rlie in 11 uren doen kan, daarvan zal zij het dubbele opleveren in 22 uren. Maar beproef dit eens met paarden, en gij zult spoedig bemcrken dat zij niet tegen de stoommachine kunnen concurreren, daar zij tijd behoeven voor rust en roeding. Een mijner geachte directenrs vertelt mij dat hij alle stadien doocloopen heeft in een fabriek, dat hij 11, 12, 13, ja zelfs 14 uren gewerkt heeft, en zich dagelijks uitgeput voelde. Hij zegt dat de arbeiders, hunne werkuren wetende, dienovereenkomstig werkten - dat bij meer en beter werk zou afgelegd hebben in korteren tijd. Er is, geloof ik, geene quaestie meer van, dat er meer slecht werk wordt afgelegd in de laatste 1 of 2 uren van den dag dan in de eerste 9 of 10 . Er kan geen twijfel meer bestaan of 11 uren zijn voldoende om iemands kracht, in welke bezigheid of betrekking ook, geheel uit te putten, hoewel de arbeid dan nog niet eens zwanr behoeft te zijn.

Het kan niet weinig aangenaam zijn voor iemand die een menigte banden aan 't werk heeft, als hij ziet dat zij gezonder en gelukkiger zijn en dan nog de gelegenheid hebben om zich wat te ontwikkelen. Die fabrieken die korter werken hebben daarbij van zelve de beste keuze van arbeiders en dan zal het eigenbelang het overige doen, ook zonder tusschenkomst der wetgeving. Ik wil hierbij nog rermelden dat wij voor 20 jaren een soort van goed maakten dat toen veel gebruikt werd. In dien tijd hadden we voor het winden van gekleurd garen te Manchester in ons pakhuis ongeveer 30 vrouwen aan het werk, die niet beneden de 20 en boven de 40 jaren waren. Ten einde deze meer werk te doen afleggen verzocht ik dat zij 12 , in plats van 11 uren zonden werken. Aan het einde der week voud ik dat zij slechts weinig meer gedaan hadden, doch, meenende dat er een of ander onvoorzien geval had plaats gehad, verzocht ik dat zij de volgende week 13 uren zouden arbeiden. Toen deze week voorbij was, badden zij nog minder in plats van meer gedaan. De meesterknecht zeide mij dat de werkuren te lang waren en verzocht mij in de werkzaal te komen als zij er het latste uur doorbragten. Ik zag dat ze uitgeput en slaperig waren, en weinig en slecht werk deden. Ik verminderde den werktijd met twee uren even als vroeger en sedert dien tijd ben ik een voorstander van vermindering der werkuren geweest."

(get.) Robert Gardner. 
Hoe gelukkig zou het voor ous laud ziju iudien dergelijke voorbeelden navolging mogten vinden. Maar boe nu, als dit het geval niet eens ware; zal men dan blijven voortgaan op de wijze die tot nu toe gebruikelijk is? De opinien komen niet overeen bij de beantwoording dezer vraag.

Er zijn er die, volgens de leer van Jeremias Bentham, den grooten utiliteitsman, zeggen dat men de zaak maar aan zich zelve moet overjaten, omdat het welbegrepen eigenbelang nooit met bel belang van het algemeen kan strijden. Dit is nu wel waar, doch het komt alles aan op dat woordje welbegrepen eigenbelang, en hoe velen zijn er niet die als fabrikanten sterven, eer zij dat welbegrepen eigenbelang goed hebben ingezien. - Men zal toch niet beweren, dat een ieder die maar steeds door op zijne wijze zijn eigen aardsche welzijn zocht, daarbij het meest tot dat algemeene welziju medewerkt. Wel degelijk is het zaak hem dáár voor te lichten, waar zijn gemeend eigenbelang aan de ware belangen van anderen in den weg staat. Daar uu helaas, velen onzer nijverheidondernemers vog meenen dat zij hun eigenbelang het meest bevorderen door hunne werklieden maar zoo veel en zoo lang mogelijk per dag te lateu arbeiden, geloof ik niet dat die ware harmonie tusschen eigen en anderer belang algemeen voldoende wordt ingezien, om voor als nog veel heils van de eenvoudige toepassing van Bentham's leuze te mogen verwachten. - „Maar die werkmenschen krijgen immers loon volgens de vrije concurrentie, op de algemeene arbeidsmarkt," zoo hooren wij ons reeds toeroepen. Maar eilieve, zal de geringe loonverhooging, zoo die er is, hem den dag (voor arbeid, voeding, rust, en toch eenige ontwikkeling en ontspanning) langer dan 24 uren kunnen maken? Welk welzijn geeft hem dat loon, als zijn leven zoo doende niet anders zijn kau dan eene afwisseling van kort slapen en lang arbeiden, gestoorde voeding, steeds onderdrukte ligchaamsontwikkeling; als hij geen tijd heeft voor eenige geestontwikkeling, waarin toch immers het doel des levens bestaat?

Maar zal de wetgever dat kwaad kunnen opheffen? - Er zijn er die zulks bevestigend beantwoorden en vau meening zijn dat hij het kwaad door eene wettelijke regeling grootendeels zou kumnen voorkomen. Met deze meening zou $\mathrm{ik}$ mij ook zeer goed kunuen vereenigen, zoo $\mathrm{ik}$ nog niet meer van de werking van het welbegrepen eigenbelang verwachtte. Het is daarom nuttig voorbeelden bij te brengen die het bewijs leveren dat het ware belang van meester en arbeider meer in harmonie is dan men welligt dikwijls denkt, en dat „Jang arbeiden niet altijd gelijk staat met reel werk leveren."

\section{S. L. P.}

